\title{
MEMAKNAI LUKISAN GUA UHALIE: PENDEKATAN STRUKTURALISME LÉVI STRAUSS
}

\author{
The meaning of Rock Art Uhalie Cave: \\ Lévi Strauss Structuralism Approach \\ A. Muh. Saiful \\ Balai Arkeologi Sulawesi Selatan \\ Jl. Pajjaiyang No. 13 Sudiang Raya Makassar, Indonesia \\ ifulk.fullah@yahoo.co.id
}

\begin{abstract}
Naskah diterima: 21/03/2018; direvisi: 01/04-20/04/2018; disetujui: 20/07/2018
Publikasi ejurnal: 31/07/2018
\end{abstract}

\begin{abstract}
South Sulawesi is an area that has many prehistoric painting sites. Research on the meaning of the painting is still very limited. Therefore this paper attempts to examine the meaning contained the Uhalie Cave site by Lévi Strauss structuralism approach. The issues raised in this paper are how the meaning of Uhalie Cave paintings and why anoa and pigs became the object of paintings in the Uhalie Cave. The answer obtained from the issues will explain the behavior of a group of painters located in the village. The methods used in this study are collecting secondary data of Uhalie Cave Research, then doing analysis of painting classiffication, finding the pattern of painting in the cave, finding sintagmatic, paradigmatic, tansformation, determining signified-signifer, and distinctive feature. The result of this study explain that the happines and grief manifestation of Uhalie Cave human in hunting.
\end{abstract}

Keyword: : Painting, meaning, structuralism Lévi Strauss.

\begin{abstract}
Abstrak
Sulawesi Selatan merupakan wilayah yang memiliki banyak situs lukisan prasejarah. Penelitian terhadap makna lukisan tersebut masih sangat terbatas, oleh karena itu karya tulis ini mencoba mengkaji makna yang terkandung pada situs Gua Uhalie dengan menggunakan pendekatan strukturalisme Lévi Strauss. Masalah yang diangkat dalam tulisan ini adalah bagaimana makna lukisan Gua Uhalie dan mengapa anoa dan babi menjadi objek lukis di Gua Uhalie. Jawaban yang didapatkan dari permasalahan tersebut akan menjelaskan tingkahlaku kelompok pelukis yang terletak di daerah pedalaman. Metode yang digunakan dalam penelitian ini mengumpulkan data sekunder hasil penelitian Gua Uhalie kemudian melakukan analisis klasifikasi lukisan, menemukan pola keletakannya, menentukan tanda-penanda (signified-signifer), sintagmatik, paradigmatik dan transformasi, serta menentukan ciri pembedanya (distictive feature). Hasil penelitian ini menjelaskan bahwa lukisan tersebut merupakan perwujudan suka duka manusia pendukung Gua Uhalie dalam melakukan perburuan.
\end{abstract}

Kata Kunci: Lukisan, makna, strukturalisme Lévi Strauss.

\section{PENDAHULUAN}

Sepuluh tahun belakangan ini, penelitian terhadap lukisan dinding pada gua-gua prasejarah di Sulawesi Selatan terhitung masih sedikit. Padahal di Sulawesi Selatan situs-situs arkeologi yang memiliki lukisan dinding sangat banyak. Situs tersebut tersebar di kawasan kars Maros, Pangkep, dan Bone. Dalam kurun waktu tersebut penelitian yang telah dilakukan berada pada tataran eksploratif, identifikasi, kronologi, hubungan-hubungan hingga pada tataran penelitian penemuan makna yang dikandungnya. Diantara penerapanpenerapan yang telah dilakukan, akhirnya melahirkan pandangan bahwa kajian dalam menemukan makna suatu lukisan perlu dikembangkan guna mengetahui bagaimana sebab dan tujuan si-pembuat melahirkan ide atau gagasannya. Apakah gagasan itu bermakna personal atau bermakna kolektif. 
Selama kurun waktu tersebut, penelitian lukisan prasejarah Sulawesi Selatan diantaranya telah dilakukan oleh Balai Arkeologi Makassar (2011) mengeksplorasi Gua Batti di Kabupaten Bone (Hakim, 2011). Tahun 2012, Keluarga Mahasiswa Arkeologi (KAISAR) Universitas Hasanuddin mengunjungi situs Gua Uhalie atas informasi dari warga sekitar (KAISAR, 2012). Laporan dari KAISAR kemudian ditindak lanjuti oleh Balai Pelestarian Cagar Budaya (BPCB) Makassar (2013) dengan eksplorasi yang lebih dalam. Hasil eksplorasi tersebut menjelaskan bahwa Gua Uhalie memiliki lukisan sebanyak 142 yang terdiri dari lukisan telapak tangan dan binatang (BPCB Makassar, 2013).

Penelitian dalam tataran identifikasi diantaranya mengenai objek lukis berupa perahu di Maros dan Pangkep (Syahdar, 2006), identifikasi lukisan fauna perairan di Pangkep (Handayani, 2015) dan identifikasi fauna Gua Uhalie di Bontocani, Bone (Arizona, 2012). Penelitian dengan menerapkan kajian simbol pernah dilakukan di Gua Garunggung dengan menggunakan pendekatan semiotika (Asfriyanto, 2006) dan penelitian pola keletakan bentuk lukisan tangan di Kabupaten Pangkep dan Maros dengan menggunakan pendektan formal (Permana, 2008). Penelitian terakhir adalah penentuan usia lukisan yang terdapat di Maros dengan menggunakan sampel dari unsur ornamen gua berupa small Coralloid yang menempel pada permukaan lukisan (Aubert et al., 2014).

Berdasarkan pustaka di atas, penelitian dalam tataran penemuan makna hanya dilakukan oleh Asfriyanto dan Permana. Oleh karena itu dalam kesempatan ini penulis akan melakukan penelitian yang sama dengan menggunakan pendekatan yang berbeda. Adapun situs yang menjadi objek penelitan ini adalah Gua Uhalie. Gua Uhalie merupakan gua yang memiliki lukisan telapak tangan dan hewan bercirikan berasal dari masa plestosen akhir. Penulis memilih gua Uhalie karena gua ini memiliki lukisan terbanyak dibanding dengan gua lainnya yang terdapat di Sulawesi Selatan. Unsur banyak itu dianggap salah satu syarat utama yang memungkinkan menyimpan fenomena struktur seperti paradigmatik, sintagmatik, transformasi, dan oposisi. Selain alasan itu, keberadaan lukisan babi dan anoa di Gua Uhalie merupakan fenomena tentang wujud binatang mamalia yang selalu menjadi objek gambar. Padahal diketahui bahwa di dalam hutan Sulawesi terdapat beberapa binatang endemik mamalia lainnya yang hidup dalam lingkungan yang sama. Ekskavasi arkeologi telah membuktikan bahwa pada situs gua terdapat jenis binatang lainnya yang sering ditemukan berada dalam asosasi dan layer budaya yang sama dengan anoa dan babi, seperti kuskus, monyet, musang, dan tarsius (Glover, 1978; Heekeren, 1972; Mulvaney \& Soejono, 1970) tetapi binatang-binatang tersebut hingga hari ini belum ditemukan sebagai objek gambar manusia di masa lalu. Oleh karena itu, penulis berasumsi bahwa kahadiran gambar binatang anoa dan babi sebagai objek gambar bukan semata-mata perwujudan sebagai hewan buruan atau unsur seni semata tetapi terdapat faktor lain yang menyebabkan perwujudannya sebagai objek lukis. Beranjak dari alasan itu penulis kemudian terdorong untuk melakukan penelitian dengan menggunakan pendekatan strukturalisme Lévi Strauss agar dapat memberikan makna terhadap lukisanlukisan di gua Uhalie. Maka dari itu, pertanyaan yang akan dijawab dalam penelitian ini adalah: Bagaimana makna yang dikandung lukisan situs gua Uhalie?; dan mengapa lukisan babi dan anoa menjadi objek lukis?

Untuk menjawab pertanyaan di atas, sekiranya kita perlu memahami apa dan bagaimana arkeologi struktur dan strukturalisme Lévi Strauss bekerja. Arkeologi struktural merupakan kajian arkeologi yang menggunakan pendekatan struktural untuk menemukan makna dibalik artefak yang mengutamakan pemikiran 
tentang dunia dalam bentuk struktur dan disusun oleh organisasi individu terhadap relasi yang saling bergantung (Preucel, 2006, p. 93). Pendapat lainnya mendefinisikan arkeologi struktural sebagai hubungan antara berbagai komponen; hubungan timbal balik yang terorganisasikan atau sistem yang mengamati hubungan-hubungan terhadap makna, praktek, dan perubahan (Hodder, 1982). Penggunaan struktural dalam arkeologi karena artefak tidak bisa memberikan maknanya secara realitas, makna sebuah artefak tidak terlihat tetapi berada pada transformasi dan hubungan diantara perbedaan aspek artefak dan antara artefak dan masyarakat, seperti pararel, oposisi, linear, dan kesamaan-kesamaan (Tilley, 2004, p. 188). Artefak bukan hanya sebagai alat tetapi merupakan hasil dari gagasan dan perwujudan kisah yang menggunakannya (Hodder, 1982, p. 12). Arkeologi struktural menggunakan pendekatan linguistik struktural Saussure dan Jacobson (Hodder, 1982; Preucel, 2006). Untuk memahami artefak kita harus berpikir masuk dalam hubungan atau syarat yang lebih dalam dengan terlebih dahulu harus dipahami bahwa sebuah artefak berwujud karena adanya struktur yang mengikat di dalamnya.

Cara kerja yang sudah diterapkan dalam kajian arkeologi struktural adalah menganalisis perbedaan tipe artefak dengan memperhatikan atribut terkecil yang dimilikinya, memperhatikan konteks, kedudukan, pola asosiasinya serta menganalisis struktur oposisinya (Tilley, 2004, p. 190; Wyle, 2002, p. 132). Namun sebelum sampai ke tahap ini, hal yang paling mendasar perlu dipahami adalah konsep struktur itu sendiri. Jika artefak adalah bahasa, maka artefak akan diikat oleh makna yang tak terhidar dari konsep transformasi dan untuk menemukan makna harus masuk pada sistem linguistik. Artefak adalah suatu sistem simbol dan sistem tanda, dalam artian benda yang dihasilkan oleh masyarakat atau berbagai kelompok sosial di dalamnya, sadar atau tidak sadar telah mengungkapkan ideide, pandangan, yang memiliki pesan-pesan yang bersifat sosial atau individual (AhimsaPutra, n.d.). Masuk pada jalur pemaknaan tertentu diperlukan konsep bahasa sebagai sistem penandaan yang harus digunakan (Olsen, 2010, p. 41).

Ahimsa-Putra (2006) menguraikan definisi struktur menurut Levi'Strauss dan cara kerjanya dalam menemukan makna kebudayaan tertentu. Struktur adalah model untuk memahami atau menjelaskan gejala kebudayaan yang dianalisisnya yang tidak ada kaitannya dengan fenomena empiris kebudayaan itu sendiri. Model ini merupakan relasi-relasi yang berhubungan satu sama lain atau saling mempengaruhi. Dengan kata lain, struktur adalah relasi dari relasi atau sistem relasi. Struktur terbagi atas dua, yaitu struktur luar dan struktur dalam. Struktur luar adalah relasi-relasi antar unsur yang terbangun berdasarkan ciri-ciri luar atau ciri empiris dari relasi-relasi tersebut. Struktur dalam adalah susunan tertentu yang terbangun berdasarkan struktur luar yang telah dibuat. Struktur dalam ini tidak tampak secara empiris atas fenomena yang dipelajari. Struktur dalam diketahui, dilakukan dengan perbandinganperbandingan struktur luar. Analisis Struktural Lévi Strauss bekerja dengan cara, yaitu (a) mencari distinctive feature (ciri pembeda) yang membedakan tanda-tanda kebahasan satu dengan yang lain. (b) memberi suatu ciri menurut feature tersebut pada masing-masing istilah, sehingga tanda ini cukup berbeda dengan yang lain. (c) merumuskan dalil-dalil sintagmatis mengenai istilah-istilah kebahasaan mana dengan distinctive feature yang mana dapat berkombinasi dengan tanda-tanda kebahasaan tertentu. (d) menentukan perbedaan-perbedaan antara tanda yang penting secara paradigmatis, yakni perbedaan-perbedaan antar tanda yang masih dapat saling menggantikan (transformasi) dan mengetahui keberadaan 


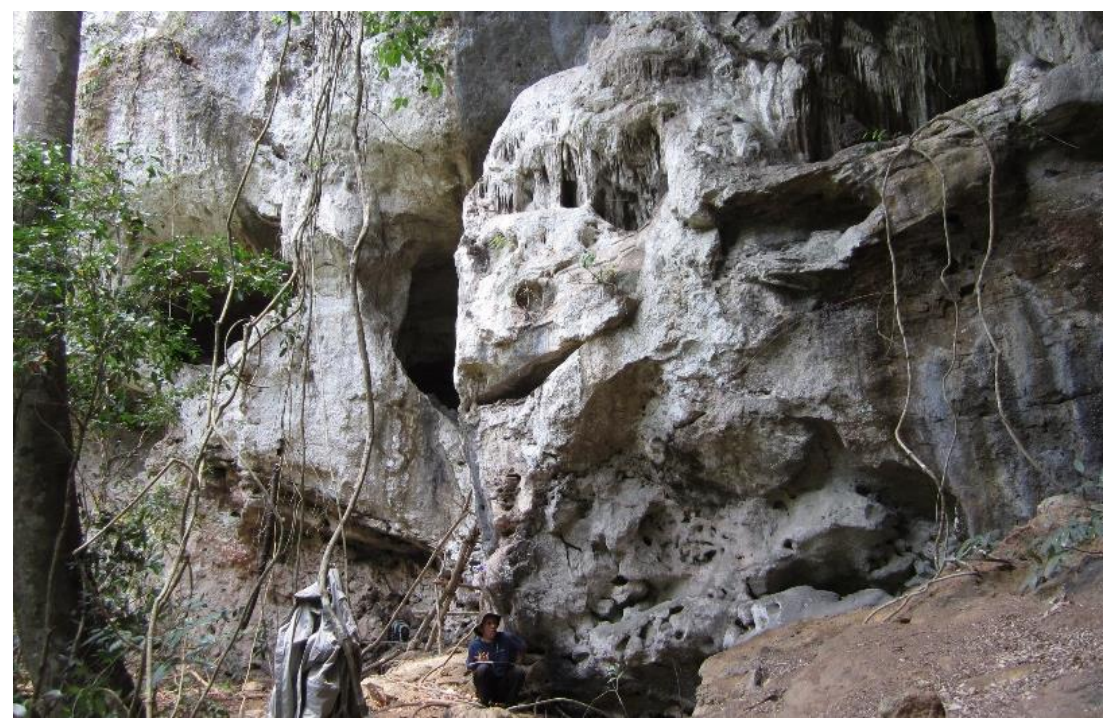

Gambar 1. Pintu masuk Gua Uhalie

(Sumber: Dokumentasi BPCB Makassar, 2013)

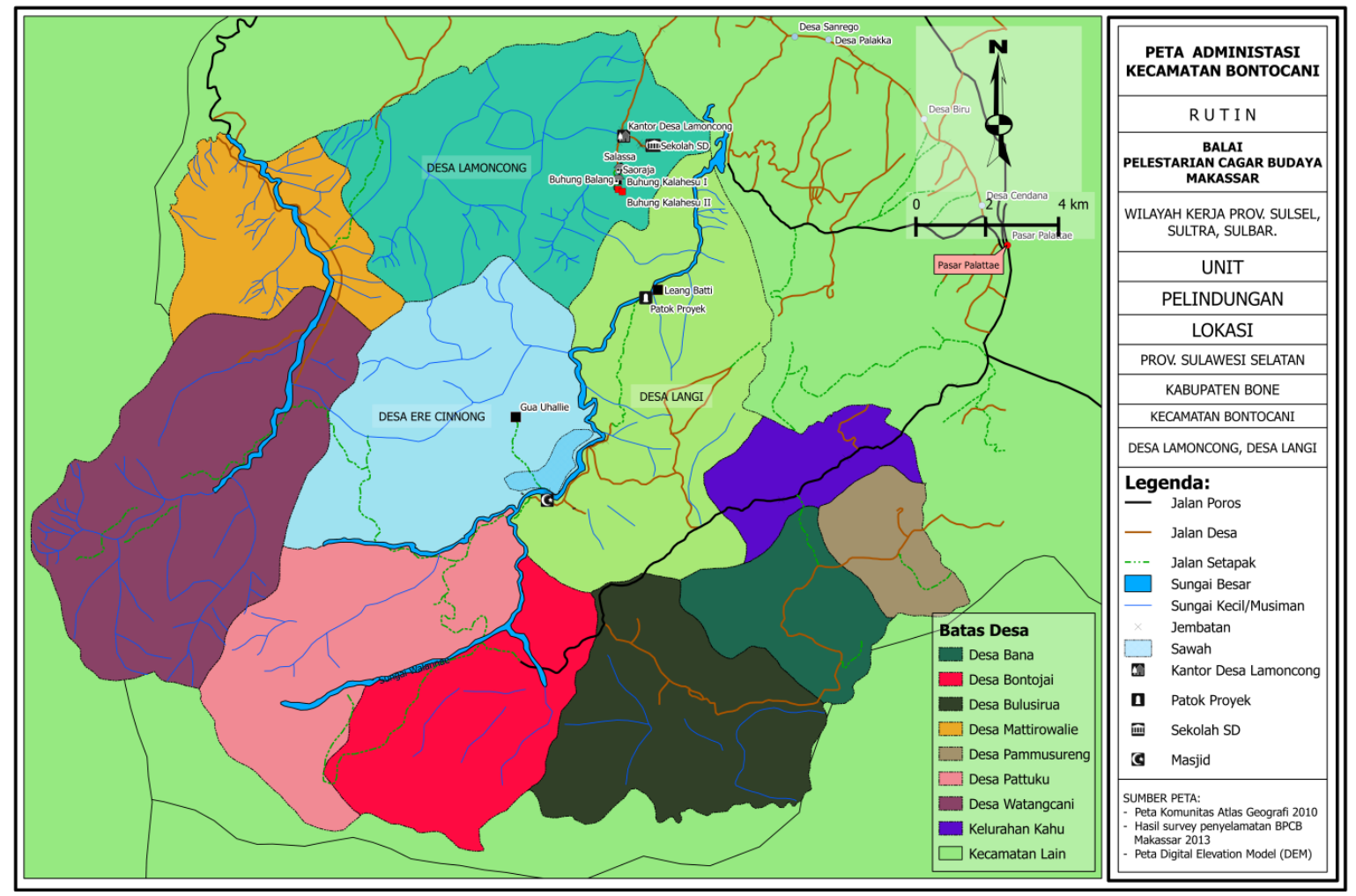

Gambar 2. Peta lokasi Gua Uhalie di Kecamatan Bontocani

(Sumber: Dokumentasi BPCB Makassar, 2013)

fonem yang tidak dikenali atau bersifat tidak disadari oleh pengguna bahasa (AhimsaPutra, 2006).

Penjelasan definisi serta cara kerja arkeologi struktural dan struktural
Levi'Strauss yang diuraikan di atas memberi kejelasan bahwa model strukturalisme Levi' Strauss dianggap cocok diterapkan dalam menjawab pertanyaan yang telah diajukan. Dengan demikian tujuan penelitian yang 
akan dicapai adalah menemukan alasanalasan manusia di masa lalu yang melatari keinginannya dalam membuat lukisan dan memilih objek lukis dalam hal ini adalah makna luar dan makna dalam.

\section{METODE PENELITIAN}

Data yang digunakan dalam penelitian ini merupakan data sekunder yang berasal dari Laporan Survey Keluarga Mahasiswa Arkeologi Universitas Hasanuddin, Skripsi yang ditulis oleh Arizona, dan Laporan penelitian BPCB Makassar. Penulis kemudian membandingkan data yang berasal dari ketiga sumber tersebut. Penulis mengamati kesesuain letak, foto, jumlah, dan terminologi untuk tiap jenis lukisan. Penulis mengkonfirmasi terhadap salah satu anggota tim penelitian BPCB Makassar yang terlibat dalam penelitian tersebut guna memastikan posisi lukisan pada ruang gua.

Penulis mengklasifikasi semua jenis lukisan dan melihat fenomena keletakannya. Setelah itu penulis menggunakan analisis strukturalisme Lévi Strauss diantaranya analisis signified, signifier, sintagmatik, paradigmatik, transformasi, dan oposisi biner atau ciri pembeda, Hal ini dimaksudkan guna menghasilkan penjelasan struktur atau makna yang dikandungnya baik itu makna permukaan ataupun makna dalam. Oleh karena itu apabila metode ini bekerja dengan menggunakan gambar gua sebagai objek, maka yang dilakukan adalah menandai semua gambar (signifiedsignifier), menentukan asosiasi dalam tiap panel, mengamati hubungan antar tiap panel dan fenomena yang dihasilkannya. Selanjutnya, mengamati pergantian gambar yang terjadi antar tiap panel (sintagmatik, paradigmatik, transformasi), dan mengamati setiap gambar yang memiliki hubungan terbalik atau ciri pembeda (binary oposition).

\section{HASIL DAN PEMBAHASAN}

1. Gua Uhalie

Gua Uhallie terletak di Dusun Kalukue, Desa Langi Kecamatan Bontocani,
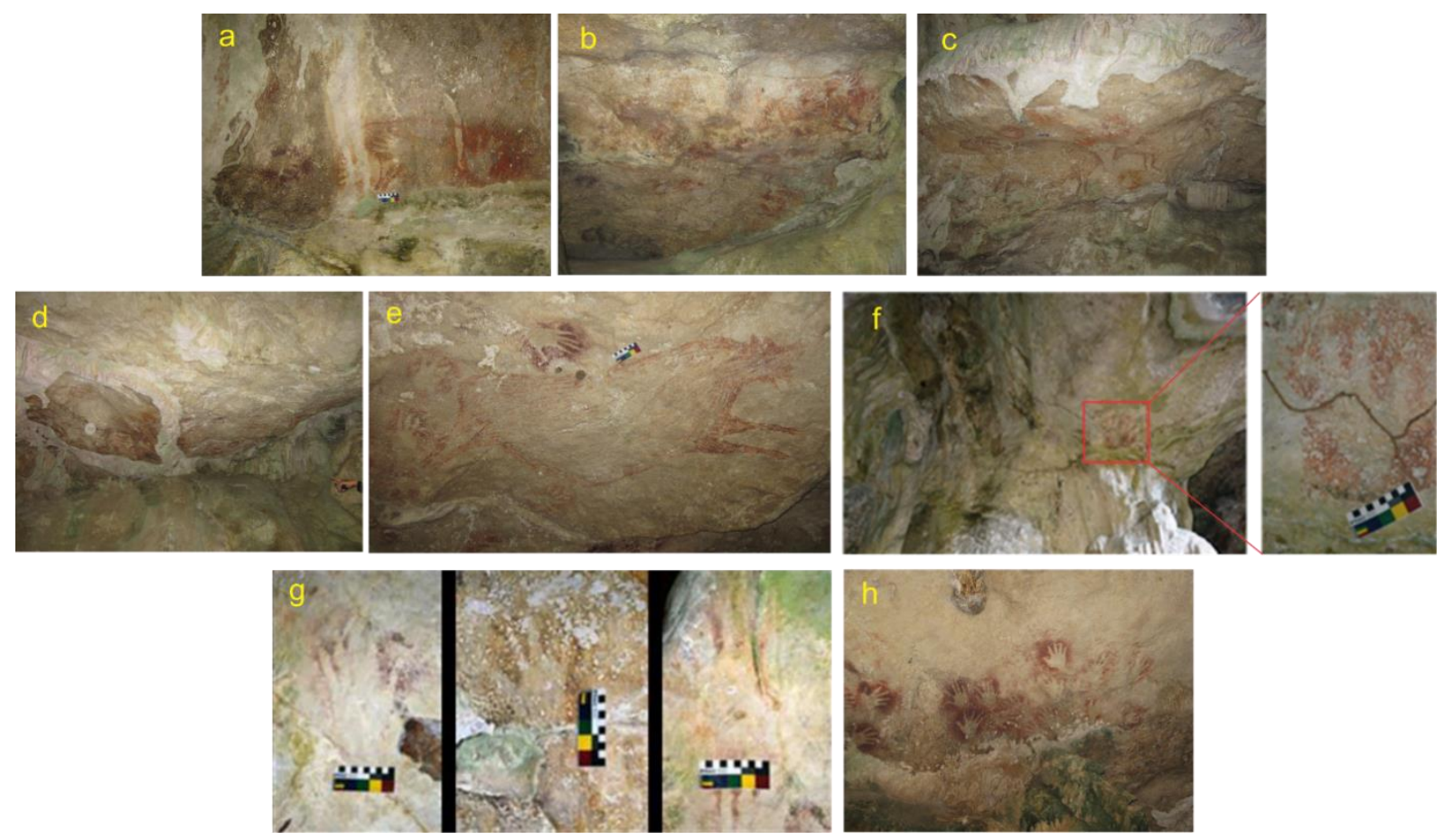

Gambar 3. a) panel 1, b) panel 2, c) panel 3, d) panel 4, e) panel 5, f) panel 6, g) panel 7, h) panel 8

(Sumber: Dokumentasi BPCB Makassar, 2013 dengan modifikasi) 


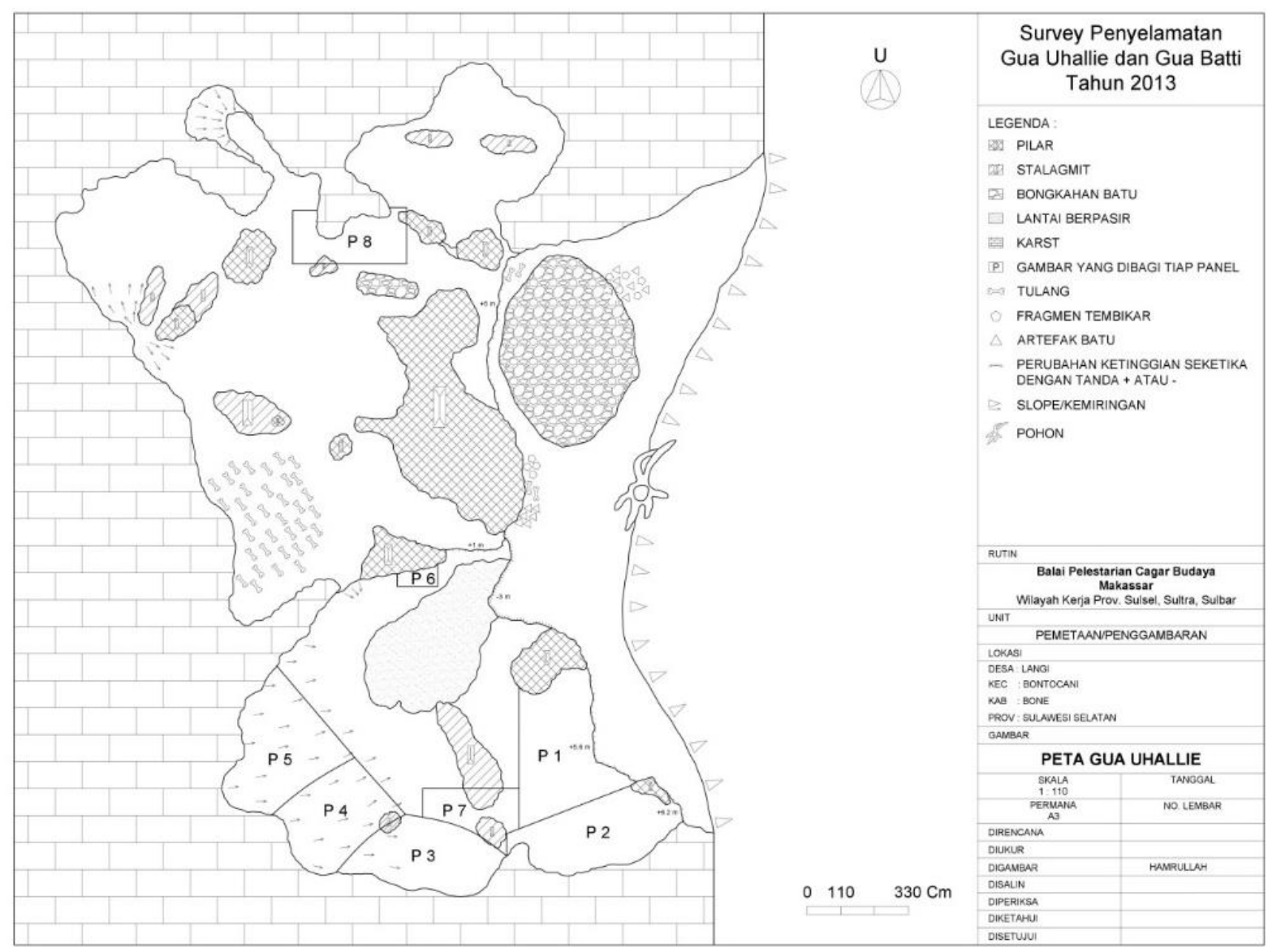

Gambar 4. Peta Gua Uhalie

(Sumber: Dokumentasi BPCB Makassar, 2013)

Kabupaten Bone, Provinsi Sulawesi Selatan. Secara astronomis terletak pada $5^{\circ} 01^{\prime} 2.38^{\prime \prime}$ LS dan $119^{\circ} 58^{\prime} 7.42^{\prime}$ ' BT dan berada pada ketinggian $621 \mathrm{mdpl}$. Orientasi gua timurbarat dan merupakan gua yang memanjang ke samping, memiliki beberapa ruang, dan dua mulut gua. Mulut utama gua memiliki panjang $10,1 \mathrm{~m}$ dan tinggi $5 \mathrm{~m}$. Kondisi suhu pada gua berkisar antara $25^{\circ}-30^{\circ} \mathrm{C}$. Gua ini memiliki pelataran yang cukup luas dengan panjang 28, $26 \mathrm{~m}$ dan lebar 4, $93 \mathrm{~m}$.

Jumlah lukisan yang ditemukan di Gua Uhalie sebanyak 142 yang terdiri atas lukisan telapak tangan berpergelangan dan telapak tangan sebanyak 135 dan lukisan binatang sebanyak 7. Lukisan tersebut terkonsentrasi pada 8 panel. Panel 1 sebanyak 6 lukisan, panel 2 sebanyak 27 lukisan, panel 3 sebanyak 21 lukisan, panel 4 sebanyak 41 lukisan, panel 5 sebanyak 22 lukisan, panel 6 sebanyak 1 lukisan, panel 7 sebanyak 3 lukisan, dan panel 8 sebanyak 18 lukisan. Adapun lukisan binatang ditemukan di panel 1, 2, 3, 4, dan 5 .

Secara keseluruhan tipe lukisan yang ditemukan terdiri atas tangan (kanan dan kiri), telapak tangan (kanan dan kiri), bentuk ujung jari (bulat dan runcing), jumlah jari (lengkap dan tidak lengkap). Jenis binatang (babi dan anoa), lukisan binatang (sempurna; seluruh anggota badan terlihat dan tidak sempurna; hanya setengah anggota badan), gerak lukisan binatang (aktif dan tidak aktif). Letak konsentrasi telapak tangan di sekitar lukisan binatang (atas, bawah, depan, belakang), jenis kelamin binatang (jantan) dan letak panel atau konsentrasi (keseluruhan di langit-langit). 
Tabel 1. Himpunan gambar berdasarkan ciri khusus yang dimilikinya

\begin{tabular}{cccc}
\hline Panel & $\begin{array}{c}\text { ttb dan telapak tangan } \\
\text { kanan manusia }\end{array}$ & $\begin{array}{c}\text { ttb dan telapak tangan } \\
\text { kiri manusia }\end{array}$ & hewan \\
\hline panel 1 & $\begin{array}{c}\text { ttb dan telapak tangan } \\
\text { kanan }\end{array}$ & ttb dan telapak tangan kiri & $\begin{array}{c}\text { tidak } \\
\text { teridentifikasi }\end{array}$ \\
\hline panel 2 & $\begin{array}{c}\text { ttb dan telapak tangan } \\
\text { kanan }\end{array}$ & ttb dan telapak tangan kiri & babi \\
\hline panel 3 & $\begin{array}{c}\text { ttb dan telapak tangan } \\
\text { kanan }\end{array}$ & ttb dan telapak tangan kiri & anoa \\
\hline panel 4 & $\begin{array}{c}\text { ttb dan telapak tangan } \\
\text { kanan }\end{array}$ & ttb dan telapak tangan kiri & anoa \\
\hline panel 5 & $\begin{array}{c}\text { ttb dan telapak tangan } \\
\text { kanan }\end{array}$ & ttb dan telapak tangan kiri & babi \\
\hline panel 6 & ttb dan telapak tangan \\
panel 7 & ttb dan telapan tangan kiri & 0 \\
\hline panel 8 & ttb dan telapak tangan tangan kiri \\
& kanan & ttb dan telapak tangan kiri & 0 \\
\hline
\end{tabular}

\section{Analisis Struktural Lévi Strauss Terhadap Lukisan Dinding Gua Uhalie}

\section{a. Signified-signifier}

Signified (tinanda atau yang ditandai) dan Signifier (penanda) merupakan langkah paling awal untuk memberikan bunyi berupa kata pada lukisan yang ditemui di gua Uhalie. Dalam hal ini berbagai jenis lukisan merupakan konsep/ tinanda dan bunyi berupa kata adalah penandanya (Lampiran 1).

\section{b. Sintagmatik, Paradigmatik, dan transformasi}

Lukisan yang terdapat pada gua Uhalie terkonsentrasi pada 8 titik atau tempat. Tempat ini kemudian diberi istilah panel. Tiap panel memiliki 3 himpunan lukisan, yaitu telapak tangan berpergelangan $(\mathrm{ttb})+$ telapak tangan + lukisan hewan. tiga himpunan lukisan ini terdapat di 5 panel. Oleh karena itu ketiga jenis himpunan lukisan tersebut memiliki hubunganhubungan karena hal ini menunjukkan adanya relasi antar komponen dalam satu struktur (Hoed, 2011, p. 31). Di bawah ini, ditampilkan tabel yang merupakan himpunan dari beberapa atribut atau ciri khusus yang ditemui pada lukisan gua Uhalie (tabel 1).

Berdasarkan tabel di atas, maka sintagmatik terlihat pada relasi antara telapak tangan berpergelangan atau yang memiliki pergelangan (ttb) kanan, telapak tangan berpergelangan atau yang memiliki pergelangan (ttb) kiri, dan hewan (babi dan anoa). Relasi ketiga himpunan tersebut ditemukan mulai dari panel 1 sampai panel 5. Sedangkan pada panel 6 tidak memiliki relasi atau hubungan sintagmatik, lalu panel ke 7 dan ke 8 hubungan sintagmatiknya ditunjukkan relasi antara ttb dan telapak tangan kanan dan ttb dan telapak tangan kiri.

Hubungan paradigmatik pada tabel di atas, ditunjukkan dengan adanya pergantian jenis hewan pada panel 1 (hewan tidak teridentifikasi ) ke panel 2 (babi), panel 2 ke panel 3 (anoa), panel 3 (2 ekor anoa) ke panel 4 (1 ekor anoa), panel 4 ke panel 5 (babi). Sedangkan pada panel 6, 7, dan 8 tidak memperlihatkan adanya hubungan paradigmatik karena ke tiga panel ini tidak memiliki atribut pada himpunan hewan. 
Tabel 2. Konsentrasi telapak tangan terhadap hewan pada tiap panel

\begin{tabular}{|c|c|c|c|c|c|c|c|c|}
\hline \multirow[t]{2}{*}{ panel } & \multicolumn{3}{|c|}{ binatang } & \multicolumn{5}{|c|}{$\begin{array}{l}\text { konsentrasi lukisan tangan dan telapak } \\
\text { tangan di sekitar lukisan binatang }\end{array}$} \\
\hline & UI & anoa & babi & depan & belakang & atas & bawah & badan \\
\hline 1 & 1 & & & & & & & $\sqrt{ }$ \\
\hline 2 & & & 2 & & $\sqrt{ }$ & & $\sqrt{ }$ & \\
\hline 3 & & 2 & & & & $\sqrt{ }$ & & \\
\hline 4 & & 1 & & $\sqrt{ }$ & & & $\sqrt{ }$ & \\
\hline 5 & & & 1 & & $\sqrt{ }$ & $\sqrt{ }$ & $\sqrt{ }$ & \\
\hline \multicolumn{9}{|l|}{6} \\
\hline 7 & & & & & & & & \\
\hline
\end{tabular}

Berdasarkan dari tabel himpunan artefak di atas, tampaknya konsep transformasi tidak ditemukan pada lukisan Gua Uhalie. Hal ini dikarenakan tidak ada perubahan himpunan atribut yang terjadi secara keseluruhan pada tiap panel.

Data arkeologi yang telah dianalisis menggunakan konsep sintagmatik dan paradigmatik di atas memunculkan struktur permukaan berdasarkan relasi "ttb dan telapak tangan kanan + ttb telapak tangan kiri + hewan tidak teridentifikasi + babi + anoa”. Relasi tersebut menunjukkan struktur luar "ttb dan telapak tangan kanan + ttb telapak tangan kiri" yang dimaknakan sebagai manusia dan "hewan tidak teridentifikasi + babi + anoa" dimaknakan sebagai hewan. Maka jelaslah bahwa pembuat kebudayaan tersebut mewujudkan konsep hubungan antara dirinya dengan hewan.

Selanjutnya jika menganalisis posisi konsentrasi telapak tangan pada tiap panel yang berasosiasi dengan lukisan hewan,

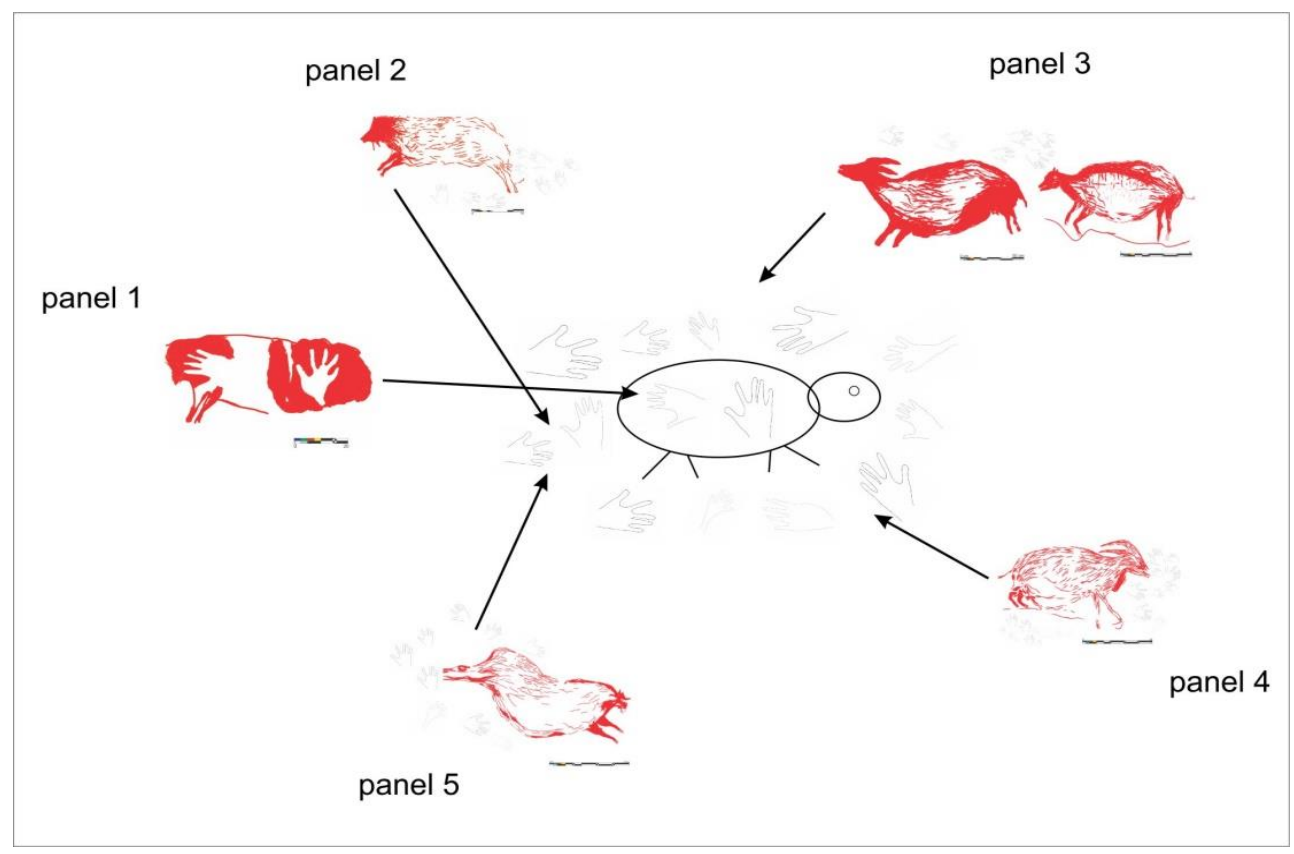

Gambar 5. Konsentrasi lukisan ttb dan telapak tangan yag mengelilingi hewan

(Sumber: Dokumentasi Arizona, 2012 dengan modifikasi) 
maka akan memperlihatkan transformasi dari panel 1 ke panel 2, yaitu binatang yang tak teridentifikasi dimana telapak tangan berada pada badan hewan bertransformasi di panel dua menjadi hewan babi dimana posisi konsentrasi lukisan ttb dan telapak tangan berada di luar badan hewan yaitu terletak di belakang dan bagian bawah hewan. transformasi berikutnya adalah panel $2 \mathrm{ke}$ panel 3, dimana pada panel 2 hewan babi bertransformasi menjadi menjadi hewan anoa di panel 3 dan konsentrasi lukisan ttb dan telapak tangan di panel 2 berada di bagian belakang dan bawah bertransformasi di panel 3 yaitu berada di bagian atas hewan anoa. Panel 3 ke 4 juga menunjukkan transformasi, yaitu hewan di panel 4 kembali menjadi babi dan konsentrasi lukisan ttb dan telapak tangan berada di bagian depan dan bawah hewan babi. Panel 4 ke 5 tidak memperlihatkan adanya transformasi. Oleh karena itu, meskipun hewan berganti dan letak konsentrasi ttb dan telapak tangan juga berganti, pergantian itu tidak mengubah makna yang terkandung dalam panel lukisan tersebut, yaitu tetap menunjukkan hubungan manusia dan hewan .

Konsentrasi lukisan tersebut menunjukkan sebuah pola dimana konsentrasi lukisan ttb dan telapak tangan diletakkan di sekitar tubuh binatang pada bagian tertentu. Jadi, jika konsentrasi lukisan tersebut disatukan, maka akan memperlihatkan sebuah pola konsentrasi lukisan ttb dan telapak tangan yang mengelilingi hewan karena semua bagian atau arah yaitu atas - bawah - depan belakang terisi dengan konsentrasi lukisan ttb dan telapak tangan. Maka, makna yang akan diperoleh dari gejala tersebut, yaitu "penguasaan", "dominasi”, atau superioritas manusia terhadap binatang.

\section{c. Distinctive Feature}

Distinctive feature disusun dengan melihat binary opposition. Binary opposition merupakan bagian yang selalu hadir yang sifatnya tidak disadari (Preucel,
2006, p. 38) dan merupakan prinsip kerja otak manusia yang menyimpan arti yang tersembunyi (Berger, 2015, pp. 228-229). Adapun binary opposition yang ditemukan adalah sebagai berikut:

\section{Oposisi Pada Manusia}

\section{Telapak tangan: telapak tangan} berpergelangan. Oposisi telapak tangan dan telapak tangan berpergelangan merupakan 2 oposisi yang hampir sama. Letak perbedaannya ditandai dengan adanya pergelangan tangan yang menghubungkan dengan lengan. Pada dasarnya keduanya sama-sama mewujudkan tangan, tetapi disini perlu dipikirkan bahwa tentu tidak serta merta mereka menggambar dua wujud yang serupa tetapi tak sama. Satu lukisan mewujudkan bagian kecil dari anggota tubuh manusia, sedangkan lukisan satunya melukiskan bagian yang sedikit lebih lengkap dari bagian tubuh manusia. Jumlah lukisan tangan berpergelangan di gua Uhalie sebanyak 15, sedangkan telapak tangan sebanyak 111. Jumlah tersebut memiliki rentang yang sangat jauh. Oleh karena itu, jumlah yang sangat sedikit tersebut menunjukkan bahwa lukisan tangan berpergelangan dapat menjelaskan sesuatu yang sangat penting. Sangat penting disini bisa berkaitan dengan peristiwa atau sosok yang penting. Apabila lukisan tersebut dilihat secara kontekstual, maka lukisan telapak tangan dimaknakan individu yang biasa, sedangkan lukisan tangan berpergelangan dimaknakan individu yang penting seperti tokoh tertentu atau pemimpin.

Kanan: Kiri. Oposisi kanan dan kiri ditemukan pada 7 panel gua Uhalie. Bagian ini baik telapak tangan ataupun telapak berpergelangan diistilahkan sebagai tangan. Dalam melakukan aktifitas sehari-hari, hampir setiap orang lebih sering menggunakan tangan kanannya. 70-90\% manusia di dunia menggunakan tangan kanannya, 8-15\% menggunakan tangan kirinya, sedangkan sisanya adalah mixed- 
handheadness $^{1}, \quad$ dan ambidexterity ${ }^{2}$ (Febrianto, 2016). Biasanya tangan kiri berfungsi membantu tangan kanan. Oleh karena itu, kanan dimaknakan aktif dan kiri dimaknakan pasif atau kurang aktif. Jika makna ini dihubungkan pada konteks lukisan prasejarah apakah makna aktif dan pasif tepat?. Jika tangan kanan dan kiri ditinjau dari segi tindakan maka tangan kanan selalu behubungan dengan tindakan yang baik, sedangkan tangan kiri berhubungan dengan tindakan 'kurang baik' . Beranjak dari penjelasan tersebut, maka kanan dapat dimaknakan sebagai sesuatu yang baik, berhasil, senang sedangkan kiri dimaknakan kegagalan, kecewa. Jumlah tangan kanan 55 dan tangan kiri 71, maka unsur kegagalan, pada Gua Uhalie lebih diwujudkan atau ditampakkan.

Bulat: Runcing. Oposisi bulat: runcing terlihat pada bentuk ujung jari pada lukisan Gua Uhalie. Ujung jari dengan bentuk bulat merupakan ujung jari normal yang dimiliki setiap orang. Sedangkan ujung jari runcing dalam bentuk jari manusia yang sebenarnya tidak ada. Oleh karena itu, pelukisan ujung jari runcing pada Gua Uhalie merupakan bentuk yang tidak biasanya. Tentu bentuk runcing memiliki makna dibaliknya. Bentuk runcing tentu saja memunculkan pertanyaan, mengapa menggambar telapak tangan dengan ujung jari yang runcing?. Runcing memiliki relasi dengan tajam, melukai, tembus, dan berhubungan dengan tindakan 'kekerasan', 'sadis'. Dalam perang peluru yang digunakan memiliki ujung yang runcing, senjata tradisional masyarakat Indonesia, yaitu keris, badik, clurit memiliki ujung yang runcing, pisau bedah dokter juga memiliki ujung yang runcing, alat perjuangan bangsa Indonesia, yaitu bambu yang diruncingkan. Oleh karena itu ujung jari bulat dan runcing, jika dimaknakan

\footnotetext{
1 Penggunaan tangan kanan dan kiri memiliki kebiasaan atau keahlian masing-masing, seperti ketika menulis menggunakan tangan kanan dengan sangat baik, dan ketika melempar menggunakan tangan kiri dengan sangat baik
}

dengan melihat konteks lukisan maka bulat dimaknakan normal, biasa-biasa saja, dan runcing dimaknakan kecakapan tangan dalam berburu hewan, tangan yang sigap memperoleh hewan buruan.

\section{Jari (lengkap): Jari Tangan Tidak} Lengkap. Secara biologi tangan yang memiliki 5 jari adalah tangan yang lengkap atau sempurna, sedangkan tangan yang memiliki jari kurang dari 5 dianggap sebagai tangan yang tidak lengkap, tidak sempurna atau cacat. Tangan yang memiliki jari yang lengkap akan lebih muda melakukan aktifitas dan peluang berhasilnya lebih besar. Sedangkan tangan yang kurang dari 5 jari sedikit lebih kesusahan atau terbatas dalam melakukan aktifitas yang berkaitan dengan penggunaan tangan. Makna tangan dengan jari 5 adalah kesempurnaan, sedangkan makna tangan dengan jari kurang dari 5 adalah ketidaksempurnaan.

\section{Oposisi pada Hewan}

Anoa: Babi. Anoa dan babi merupakan binatang endemik Sulawesi yang habitatnya berada di lingkungan hutan. Anoa adalah hewan liar yang sangat sensitif terhadap kehadiran manusia. Oleh karena itu, ketika menjumpai manusia maka anoa akan bergerak dengan cepat berlari menjauh dari manusia. Babi memiliki sifat yang sama dengan anoa, hanya saja pergerakan babi lebih lambat jika dibandingkan dengan pergerakan anoa. Berdasarkan sifat liarnya, anoa juga lebih liar dengan babi, ini karena anoa binatang yang tidak bisa dijinakkan, sedangkan babi adalah binatang yang masih bisa dijinakkan. Terbukti dengan adanya penjinakan babi yang sudah dilakukan sejak 6500 - 5000 BP di Asia Timur Laut dan Cina Tengah (Larson, 2010) hingga masa sekarang. Oleh karena itu, berdasarkan oposisi anoa : babi, maka anoa dapat diartikan sebagai tenaga yang besar,

\footnotetext{
2 Penggunaan tangan kanan dan kiri sama baiknya dalam berbagai aktifitas, seperti menulis dengan menggunakan tangan kanan dan kiri sama indahnya, melempar dengan tangan kanan dan kiri sama kuatnya.
} 
kecakapan dan babi dimaknakan mudah diperoleh, tidak membutuhkan tenaga ekstra.

Melompat/berlari: Jalan. Oposisi ini hadir berdasarkan analisis bentuk gerakan hewan pada lukisan Gua Uhalie. Lukisan yang menunjukkan gerakan melompat atau berlari diwujudkan melalui lukisan babi. Sedangkan gerakan berjalan diwujudkan melalui lukisan anoa. Berdasarkan sifatnya anoa lebih liar dibandingkan dengan babi, tetapi dalam pelukisan justru anoa tampak lebih tenang, tidak reaktif. Sedangkan babi menunjukkan gerakan yang lebih liar dan reaktif. Berdasarkan wujud lukisan dan tingkahlaku kedua hewan ini maka diartikan adanya lukisan anoa yang tarlihat berjalan merupakan deskripsi aktifitas manusia yang sedang mengintai anoa. Sedangkan babi yang wujud lukisannya sedang berlari atau melompat merupakan deskripsi manusia ketika sedang melakukan aktifitas pengejaran babi. Jadi kedua lukisan tersebut memiliki makna yang berkaitan dengan aktifitas perburuan, cara berburu, yaitu mengintai dan sedang mengejar.

Jantan: Betina. Hewan yang memiliki ciri pembeda sebagai jenis kelamin jantan dan betina adalah anoa. Jantan dicirikan dengan sifat kuat, lincah, berani. Betina dicirikan dengan sifat lembut, lebih lemah, kurang berani. Ciri yang disebutkan pada jenis kelamin tersebut berelasi dengan kesulitan dan kemudahan. Oleh karena itu jika dikaitkan dalam konteks lukisan ini, maka menghasilkan makna adanya kehati-hatian dan kemudahan atau keberuntungan dalam melakukan aktifitas perburuan.

Teridentifikasi: Tidak Teridentifikasi. Teridentifikasi : tidak teridentifikasi, memiliki relasi dengan jelas : tidak jelas/abstrak. Oposisi ini mencul berdasarkan lukisan yang terdapat pada panel 1, yaitu berupa hewan yang tidak bisa diidentifikasi jenis atau spesiesnya. Ini kemudian memiliki oposisi dengan hewan yang bisa diidentifikasi yang terdapat pada panel lainnya seperti anoa dan babi. Gambar hewan yang tidak teridentifikasi kemudian melahirkan pertanyaan, mengap hewan tersebut dilukis tanpa menonjolkan identitasnya? dan mengapa lukisan telapak tangan terdapat pada badannya?. Keberadaan telapak tangan pada badan hewan tersebut merupakan ciri yang sangat berbeda dengan lukisan lainnya. Bila melihat hubungan asosiasinya terhadap lukisan di panel lainnya maka teridentifikasi: tidak teridentifikasi memaknakan "target sebagai hewan buruan dan hewan buruan yang tertangkap.

\section{Struktur Dalam (Deep structure) Lukisan Gua Uhalie}

Pada Gua Uhalie struktur luar ditemukan melalui analisis sintagmatis dan paradigmatis yang menjelaskan bahwa makna lukisan Gua Uhalie adalah hubungan tingkahlaku antara manusia dan binatang. Makna tersebut diwujudkan melalui panel 1 hingga 5 yang menampilkan lukisan telapak tangan manusia berasosiasi dengan lukisan hewan. Untuk masuk pada struktur dalamnya, ciri pembeda (distnctive feature) yang ditemukan

melalui analisis tiap atribut yang dianggap berbeda harus diklasifikasikan dan dimaknakan sesuai dengan konteksnya. Adapun disntinctive feature atau binary opposition yang ditemukan pada Gua Uhalie sebanyak 8 pasang, yang berasal dari dua pengelompokan, yaitu manusia dan hewan. Pasangan tersebut tersusun melalui binary oposisi. Binary oposisi-nya adalah:

- Manusia. Telapak tangan : telapak tangan berpergelangan, kanan : kiri, bulat : runcing, jari (lengkap) : jari tangan tidak lengkap.

- Hewan. Anoa : Babi, Melompat/berlari : Jalan, Jantan : Betina, Teridentifikasi : Tidak Teridentifikasi.

Binary Opposition pada manusia memiliki makna pemimpin dan yang dipimpin, keberhasilan dan kegagalan, skill kecakapan dan biasa-biasa saja, 
kesempurnaan. Sedangkan binary opposition pada hewan memiliki makna tenaga yang besar atau kerja keras, cara berburu yaitu mengintai dan mengejar, kehati-hatian dan keberuntungan, dan terget yang tercapai, yaitu hewan buruan yang tertangkap. Jika dianalisis lebih lanjut, maka lukisan gua Uhalie menjelaskan tentang kelompok manusia yang memiliki pemimpin dan anggota yang bekerja bersama-sama. Menjelaskan tentang aktifitas berburu dan peristiwa-peristiwa dalam melakukan perburuan. Kesuksesan dan kegagalan pernah dijalanimya, tetapi kegagalan lebih dominan terjadi. Menemukan hewan anoa dibutuhkan kecakapan, kerja keras dibanding dengan menemukan hewan babi, dan mendapatkan hewan anoa ini juga membutuhkan keberuntungan. Dalam melakukan perburuan juga menanamkan kehati-hatian, oleh karena itu kegagalan tidak semata-mata gagal mendapatkan hewan buruan tetapi mungkin kejadiakejadian yang bisa berakibat bahaya terhadap dirinya ketika sedang berburu, seperti kecelakaan. Target mereka adalah mendapatkan hewan buruan sebagai bentuk kesuksesan dan kesempurnaan. Maka makna dalam lukisan gua Uhalie adalah perwujudan suka duka sekelompok manusia dalam melakukan perburuan hewan. selanjutnya, anoa dan babi menjadi objek lukis karena kedua binatang ini melahirkan sifat komunal mereka. Kedua hewan ini bisa ditemukan dengan kerja keras, cara berburu, kecakapan, kerjasama, kehati-hatian. Kedua hewan inilah yang menciptakan pengalaman suka duka sehingga membuat kehidupan mereka berkesan.

\section{PENUTUP}

Penerapan pendekatan struktural Lévi Strauss pada situs gua Uhalie bertujuan untuk menemukan makna luar dan makna dalam lukisan. Sebanyak 142 lukisan yang terdiri atas lukisan telapak tangan berpergelangan, telapak tangan, anoa, babi, dan hewan tak teridentifikasi. Lukisan ini terkonsentrasi pada 8 panel. Hubungan sintagmatik dan paradigmatik lukisan memperlihatkan jika lukisan ini memiliki "makna luar" yaitu hubungan atau interaksi manusia dengan hewan yang terjalin secara rutin. Transformasi akan ada jika difokuskan pada konsentrasi keletakan lukisan ttb dan telapak tangan disekitar lukisan hewan. Jika transformasi keletakan lukisan ttb dan telapak tangan disatukan maka akan memunculkan pola ttb dan telapak tangan yang mengelilingi hewan. Makna pola mengelilingi hewan tersebut adalah penguasaan, dominasi, yang berhubungan dengan cara berburu. Adapun "makna dalam" lukisan yang terdapat pada gua Uhalie adalah ungkapan atau perwujudan suka duka sekelompok manusia dalam melakukan aktifitas perburuan. Anoa dan babi diwujudkan sebagai lukisan hewan karena kedua hewan ini memberikan mereka pengalaman yang berkesan dalam kehidupannya.

\section{Ucapan Terima Kasih}

Ucapan terimakasih penulis haturkan kepada Bapak Prof. Heddy Shri Ahimsa Putra dan Bapak Dr. Daud Aris Tanudirjo yang telah memperkenalkan Pendekatan StrukturStrkturalisme Levi Strauss kepada penulis. Tak luput pula penulis mengucapkan terima kasih kepada Keluarga Mahasiswa Arkeologi UNHAS, Arizona, dan BPCB Makassar yang telah menghasilkan laporan dan karya ilmiah sehingga penulis dapat menggunakannya sebagai sumber data dalam penulisan ini. Terima kasih kepada Iswadi Makkaraka yang bersedia menjadi teman diskusi untuk mengkonfirmasi semua yang berhubungan dengan Gua Uhalie. 


\section{DAFTAR PUSTAKA}

Ahimsa-Putra, H. S. (n.d.). Arca Ganesya dan Strukturalisme Levi Strauss. Centang Budaya.

Ahimsa-Putra, H. S. (2006). Strukturalisme Levi Straus Mitos Dan Karya Sastra. Yogyakarta: Kepel Press.

Arizona. (2012). Identifikasi Lukisan Fauna Gua Uhalie. Universitas Hasanuddin.

Asfriyanto. (2006). Makna Simbolik Struktur Gambar Prasejarah Dalam Ruang Skala Mikro Pada Gua Garunggung Desa Limbua Kecamatan Minasa Te’ne Kabupaten Pangkep. Universitas Hasanuddin.

Aubert, M., Brumm, A., Ramli, M., Sutikna, T., Saptomo, E. W., Hakim, B., ... Dosseto, A. (2014). Pleistocene cave art from Sulawesi, Indonesia. Nature, 514, 223-227. https://doi.org/10.1038/nature13422

Berger, A. A. (2015). Pengantar Semiotika Tanda - Tanda Dalam Kebudayaan Kontemporer. Yogyakarta: Tiara Wacana.

BPCB Makassar. (2013). Survey Penyelamatan Gua Uhalie dan Gua Batti Desa Langi Kecamatan Bontocani Kabupaten Bone. Makassar.

Febrianto, R. (2016). Dunia dan Dominasi Pengguna Tangan Kanan. Retrieved from 2eyes2ears.blogspot.com.

Glover, I. C. (1978). Survey and Excavation in The Maros District, South Sulawesi, Indonesia: The 1975 Field Saeson. Bulletin of the Indo-Pacific Prehistory Association, 1, 113114.

Hakim, B. (2011). Survei dan Ekskavasi Gua Batti, Kabupaten Bone. Makassar.

Handayani, A. S. (2015). Gambar Fauna Perairan Pada Gua-Gua Prasejarah Kawasan Kars Maros dan Pangkep. Universitas Hasanuddin.

Heekeren, V. H. (1972). The Stone Age of Indonesia. Martinus Nijhoff.

Hodder, I. (1982). Symbolic and Structural Archaeology. UK: Cambridge University Press.

Hoed, B. H. (2011). Semiotik dan Dinamika Sosial Budaya. Jakarta: Komunitas Bambu.

KAISAR. (2012). Laporan Survey Ceruk Uhalie. Makassar.

Larson, G. (2010). Pattern of East Asian Pig Domestification, Migration, and Turnover Revealed by Modern and Ancient DNA. PNAS, 7686-7691.

Mulvaney, D. J., \& Soejono, R. P. (1970). Archaeology in Sulawesi, Indonesia. Antiquity, 45, 26-33.

Olsen, B. (2010). In Defense of Thing. UK: Altamira Press.

Permana, R. C. (2008). Pola Gambar Tangan Pada Gua-Gua Prasejarah Di Wilayah PangkepMaros Sulawesi Selatan. Jakarta.

Preucel, R. W. (2006). Archaeological Semiotics. UK: Blackwell Publishing. 
Syahdar, F. A. (2006). Gambar Perahu Pada Bidang Gua-Gua Prasejarah Maros-Pangkep. Universitas Hasanuddin.

Tilley, C. (2004). Interpreteting Material Culture. In I. Hodder (Ed.), The Meaning Of Thing: Material Culture and Symbolic Expression. London and New York: Routledge Taylor and Francis Group.

Wyle, A. (2002). Thingking from Thing. UK: University of Caligornia Press. 
Lampiran 1. Gambar yang dapat ditandai (signified) dan diberi penanda (signifier) pada Gua Uhalie (Sumber: Dokuemntasi Arizona, 2012 dan BPCB Makassar, 2013)

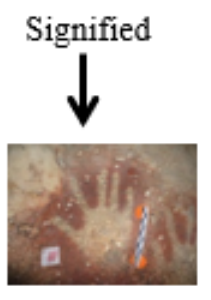

Signifier

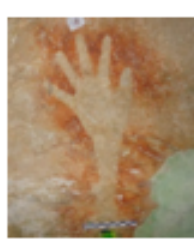

Telapak tangan

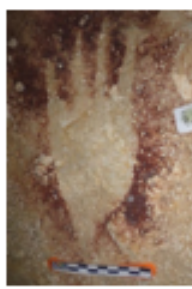

Telapak tangan berpergelangan (TTB)
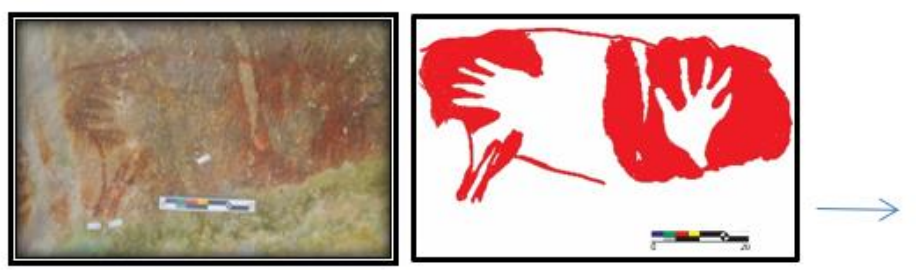

Hewan tidak teridentifikasi
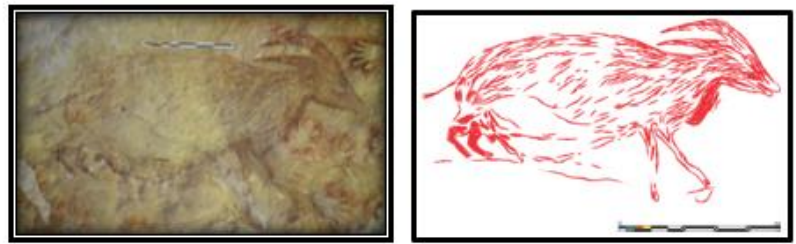

Anoa

Telapak tangan kanan

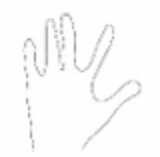

Telapak tangan jari bulat
Telapak tangan kiri

Telapak tangan jari runcing 


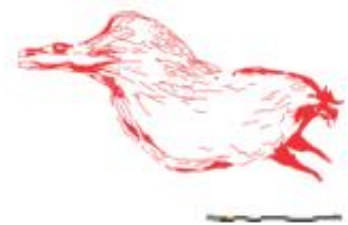

$\longrightarrow$ Melompat/ berlari

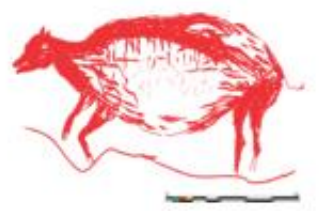

$\longrightarrow$ berjalan
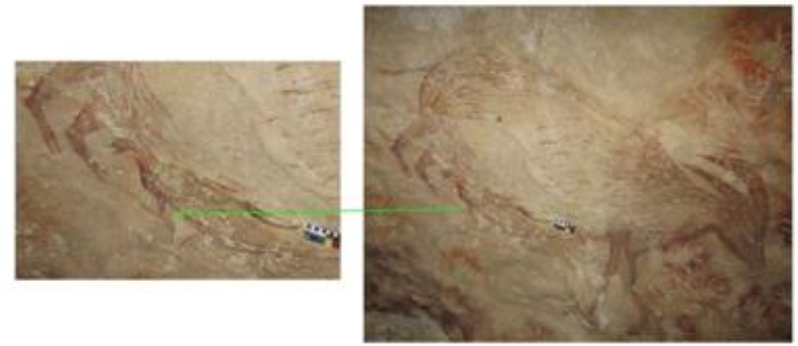

betina
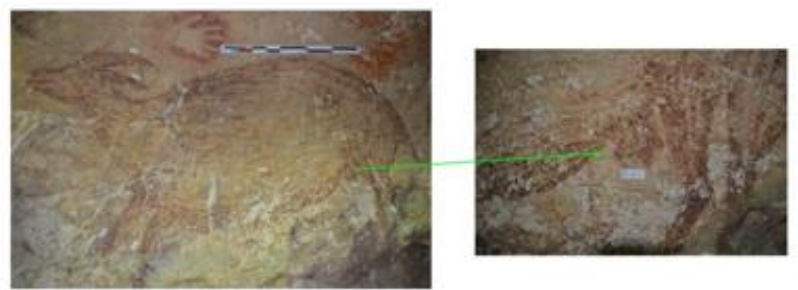

jantan 